\title{
THE UNSTABLE DEVELOPMENT OF CONTEMPORARY NATIVE AMERICAN THEATER: SITES OF CONFLICT AND DISCUSSION
}

\author{
Sidoní López Pérez \\ ${ }^{1}$ Associate Professor at Universidad Internacional de La Rioja (UNIR), Spain
}

\begin{abstract}
This essay provides a concise overview of the sites of conflict and discussion that affect contemporary Native American theater. To this effect, the paper will first explore the issue of Eurocentrism versus Nativism in order to reflect the long and difficult history of development of indigenous theater. After this initial approach, the much-discussed debate about the origins of Native drama will also be examined by focusing on two clearly distinct perspectives. In like manner, the chronological discussion about the emergence of contemporary American Indian theater will be addressed so as to review the different dates provided by several authors and scholars. Finally, the essay will explore the controversy about the geographical, political and cultural boundaries of the genre and will likewise conclude with a brief overview of the Native theater scene today with its initiatives and obstacles. As will be demonstrated, although Native American theater has a long and complex history, a great number of theater plays and a significant body of scholarship, the genre still does not enjoy a confident development, and obviously more work is needed to unleash its full potential.
\end{abstract}

Keywords: development; drama; indigenous; oral tradition; performance. 


\section{1-23 December, 2018 in Berlin - Germany}

\section{Introduction}

Even though Native American theater ${ }^{1}$ emerged as a genre in the second half of the 20th century, it has a long history of silencing, oppression, displacement and controversy that has definitely made it difficult for Native drama to develop and be recognized. The exclusion of oral traditions from the canon by their deviation from the mode of writing, the relegation of theater studies to other disciplines, the significant confusion of authorship toward the genre and the persistent confusion over what comprises and defines this literary form are among the multiple reasons often given for the discontinuous and unstable development of Native drama throughout the centuries. Apart from that, although American Indian theater has a great number of plays, a long history of theater companies and a significant amount of scholarship, there are still some controversies regarding the genre, which clearly indicate that Native theater continues to be a complex site of conflict and discussion. The much talked-of debate about the origins of Native drama, the different dates provided for the emergence of contemporary American Indian theater, the discrepancies regarding the geographical, political and cultural boundaries of the genre and the different obstacles and major issues that the Native theater scene is currently facing suggest that much work still remains to be done in order to develop a confident and consolidated American Indian theater.

\section{Eurocentrism versus Nativism}

Although contemporary Native American theater emerged around the 1950s, its origins are often traced back to the oral tradition. This tradition mainly consisted of different and multiple stories that were passed down from generation to generation in order to educate, entertain and preserve Native American cultures. These stories, which were mostly acted out and performed, are usually considered to belong to a diverse Native oral literature, which was not acknowledged until the late $20^{\text {th }}$ century, since according to the dominant Western cultures, only written texts were considered literature. As Krupat (1989) explains, "We might begin by noting that historically literature was simply the term for whatever language Western cultures deemed important enough to preserve by means of the technology of writing" (p. 38). Under this perspective, Native Americans were illiterate, only used the spoken word and were unable to develop a written culture.

As a result, the Euro-American society began to write and provide different portrayals of Native Americans through literature, focusing mainly on a series of stereotypical images. This gave rise to an extensive literature about American Indians, which offered different portrayals of these Native peoples in the eyes of Euro-Americans. However, as American Indians started to create and develop their own written literature in the $18^{\text {th }}$ century, they began to present

\footnotetext{
${ }^{1}$ Acknowledging that there are many different opinions on which terminology may be the most appropriate, the terms "Native American", "American Indian", "Native" and "indigenous" will be used interchangeably throughout the paper in order to refer more broadly to indigenous peoples of the United States. However, whenever possible the specific tribal names will be used.
} 


\section{1-23 December, 2018 in Berlin - Germany}

themselves differently, although it was not until the Native American Renaissance in the late 1960 s that this literature came into full swing. During this period of literary brilliance, many Native oral traditions were categorized as oral American Indian literature and different literary genres such as the novel, autobiography, short story and poetry began to be explored. In addition, contemporary Native American theater emerged and became a literary genre that gave American Indians the chance to present their own stories on stage and in writing, while simultaneously helping untangle the endless stereotypes and misperceptions about Native Americans. In other words, the advent of a consolidated Native American literature, including theater as its most novel genre, supposed a significant approach to Nativism and a gradual detachment from Eurocentric perspectives.

As a result of the Native American Renaissance, a considerable scholarship on American Indian literature began to flourish by the 1970s and 1980s. However, these publications hardly included Native American theater, or if they did, their number was noticeably small compared to other literary genres, especially the novel. In the first place, one could think that this absence is probably due to the nonexistence of Native American plays during those years. This, however, is far from the truth, since several Native theater plays were published during the 1960s, 1970s and 1980s. Some examples include Gerald Vizenor's A Season for All Things (1967), Monica Charles's Yanowis and Mowitch (1968), Hanay Geiogamah's Body Indian (1972), Foghorn (1973), 49 (1975), Grandma (1984) and Grandpa (1984), Spiderwoman Theater's The Three Sisters from Here to There (1982) and Bruce King's Whispers from the Other Side (1985). In addition, Geiogamah's first three plays were published in the first collection of Native American plays, entitled New Native American Drama: Three Plays (1980). At the same time, several Native theater companies ${ }^{2}$ were founded since the 1950 s in order to produce and promote the works of Native American playwrights; the Native American Theater Ensemble (NATE), Spiderwoman Theater and the Coatlicue Theater Company serve as excellent examples.

Thus, it remains clear that indigenous plays began to be written and produced since the beginning of the Native American Renaissance and therefore do not justify the absence of Native drama in scholarship in the early stages of contemporary indigenous literature. In fact, there are several aspects that could certainly account for this absence, especially if we take into consideration that American Indian theater became the only literary genre absent in the proliferation of Native literature starting in the late $18^{\text {th }}$ century (López Pérez \& Benali Taouis, 2016). The different reasons given for this nonexistence of Native American theater in early American Indian literature mainly refer to the difficult standing that theater itself has had in the canon of North American literature, the often visible separation between Native and Western theater, and the effects of colonialism. In fact, the latter reveals the restriction of American Indian theater to the fields of anthropology, ethnology and religious studies (Däwes, 2007; López Pérez \& Benali Taouis, 2016). This situation has also resulted in a terminological diffusion of the genre (Däwes, 2007), since indigenous performance traditions have often been categorized or referred to as rituals or ceremonies, thereby contributing to a visible

\footnotetext{
${ }^{2}$ For a detailed and comprehensive study of American Indian theater companies, see Sally Ann Heath's doctoral dissertation The development of Native American theater companies in the Continental United States published in 1995 .
} 


\section{1-23 December, 2018 in Berlin - Germany}

"confusion over definitions and applications of words such as 'ritual', 'ceremony', and 'theater' (Jenkins, 1975). In this respect, it should be noted that the concept of unicity of the Native universe-in which religion, politics, society and spirituality coalesce-contrasts with the European compartmentalization. Thus, the word "theater" includes many more aspects for Native Americans than those contemplated by the Western perspective.

Another factor that adds to the almost nonexistent criticism on Native drama during the early stages of contemporary indigenous literature is the significant confusion of authorship and representational authority toward the genre (Däwes, 2007). In the $18^{\text {th }}$ century, numerous plays about Native Americans began to be published by Euro-American authors, who mainly created a series of stereotypical labels that did not correspond to Native experiences. As Wilmeth (2000) explains,

For the most part plays with Indian characters have only created stereotypical Indians, dominated by the noble savage, the villainous red devil, and the Indian princess or pathetic maiden, with few of these types portrayed as real people having distinctive personalities (p. 150).

In spite of those stereotyped portrayals, the existence of these plays about Native Americans by white American authors has contributed to an unstable definition and categorization of the genre, since most of these works have often been categorized as American Indian drama. This clearly explains the fact that some of the first theater publications on Native American subjects explore plays written by non-Native authors (Haugo, 2013). However, although those plays about Native Americans are relevant to the study of the different images and portrayals of indigenous peoples in the eyes of Euro-Americans, they are not representative of Native American theater. As the Choctaw playwright LeAnne Howe points out, Native drama is "theater that is written by natives, and performed by native, tribal, indigenous, American Indian, Native American actors" (as cited in Heath, 1995, p. 14).

This whole situation of exclusion, invisibility and displacement of Native American theater has also contributed to the critics' hesitation to approach this literary genre, while simultaneously bringing issues of voice and authorship into the scene (Däwes, 2007). Consequently, questions of who should speak about Native American theater and who should define and decide which elements constitute this genre began to appear, giving rise to a new debate that continued to confront Eurocentrism and Nativism. According to Däwes (2007), there are three publications that clearly illustrate this much-discussed debate. Whereas Alan Filewood's and Jennifer Preston's works have sparked controversy for being non-Native authors talking about Native American theater, Randy Reinholz, of Choctaw heritage, was accused of appropriation: "His accusation of appropriation is mainly based on the charge that, although Reinholz originally 'knew nothing of Indian ways', he instrumentalized 'a racial characteristic, his 'Indian' blood' as a means of authentication" (as cited in Däwes, 2007, p. 58).

However, it should not be relevant or necessary to decide whether the works by Native scholars are better than those published by non-Native critics. In fact, it is important to realize that contemporary Native American theater has a long and complex history that continues to expand through a vast number of plays and a significant body of scholarship, which is certainly 


\section{1-23 December, 2018 in Berlin - Germany}

contributing to explore and shape the genre from multiple perspectives, regardless of the authors' ethnicity. As the Cherokee dramatist Diane Glancy puts it, "Anyone who can speak about Native theater can. It needs all the input and interpretation it can get" (personal communication, September 20, 2007, p. 9).

The collaboration and contributions of both Native and non-Native authors and scholars can be clearly perceived through the different critical works ${ }^{3}$ on American Indian theater that have emerged since the late $20^{\text {th }}$ century. In fact, the presence of all these critical works not only accounts for the recognition, development and visibility of this vibrant genre, but is also indicative of a certain point of confluence between Nativism and Eurocentrism (López Pérez, 2011). This seems to be clearly illustrated by the fact that both Native and non-Native authors and scholars around the globe are contributing to a noticeable scholarship on the genre by providing different angles, voices and perspectives, which seem to leave behind the continuous confrontation between Native and Western cultures. In addition, it would also be possible to talk about this confluence through contemporary Native American theater itself, since it draws from both the Native culture and the Western civilization. The genre consists of elements already in existence within Native American cultures-oral tradition and performance-and elements existing within the Euro-American style of theater-play writing. Therefore, American Indian theater could be perceived as a literary genre looking for a bridge, connection or convergence between the polarities.

\section{The debate about the origins of contemporary Native American theater}

As has been mentioned before, although contemporary Native American theater emerged around the 1950s, its origins are usually considered to draw from an extensive oral tradition, which was mainly based on indigenous traditional storytelling. This means that Native Americans relied on the spoken word to tell stories as a way to pass down their history, heritage, traditions, customs, rituals and legends across the generations. These stories were usually acted out and accompanied by different dramatic elements such as different voices, body movements, planned gestures, facial expressions, exaggerated emphasis and the like, which prove the performance and dramatization of indigenous oral storytelling traditions and "their similarities and closeness to theater" (López Pérez \& Benali Taouis, 2016, p. 94). Since the similarities between storytelling and theater are notable, many authors and critics agree that contemporary Native American theater can be perceived as a continuation of oral storytelling traditions. Whereas American professor and scholar Jeffrey F. Hunstman talks about how short narratives "have recently become recognized as the scripts of one-person dramas" (2000, p. 88), German professor and scholar Henning Schäfer states that "the storytellers have always been performers" (2013, p. 31). The Oneida/Chippewa playwright Bruce King says that "theater and performance are about storytelling" (2000, p. 167), and the Ojibway playwright, author and journalist Drew Hayden Taylor talks about theater as "the next logical progression in oral storytelling - the ability to take the audience on a journey using your mind, your body and your imagination" (personal communication, August 8, 2007, p. 3).

\footnotetext{
${ }^{3}$ The various critical works on Native American drama have been reviewed by López Pérez \& Benali Taouis (2016) in their essay "Native American theater: A concise history".
} 


\section{1-23 December, 2018 in Berlin - Germany}

The same holds true for the Native playwrights in Spiderwoman Theater, who claim to base their productions on the so-called "storyweaving" technique (Haugo, 2000a, p. 238), which is similar to the process followed by the Coatlicue Theater Company, whose dramatists and artists weave traditional with contemporary stories in the writing and production of their plays (Haugo, 2000a).

However, some other critics and authors suggest that contemporary Native American theater emerged from rituals and ceremonies. In Wilmeth and Miller's edition of The Cambridge Guide of American Theater (1996), contributors make it clear that "Native American theatre is rooted in communal celebrations and ancient rituals reflecting the religious outlook and shared values of the indigenous nations that created it" (p. 276). This perspective seems to be shared by the American professor Jeffrey Huntsman (2000), who discusses and analyzes different rituals, ceremonies and performance practices by Native Americans that he categorizes as traditional ritual dramas. Although Huntsman (2000) observes a clear link between performance and tale telling by certainly acknowledging that some traditional legends and short narratives, "often indiscriminately, have recently become recognized as the scripts of one-person drama" (p. 88), he suggests that contemporary Native American theater is a continuation of those types of traditional dramas that he avidly analyzes. In addition, the Kiowa/Delaware playwright Hanay Geiogamah also calls for an integration of rituals, ceremonies and spirituality as part of a traditional theater that he explicitly categorizes as "ceremonial American Indian theater" $(2011$, p. 5). The author includes different ritual and ceremonial elements within the realm of Native American theater, and he clearly states that

As long as there has been play-acting, shamans, storytellers, entertainers, sorcerers, witch doctors, and medicine men, all of these figures in a community of people, there has been theater. The things that they did-the chants, music, enactments, recreations of animal behavior-all that was theater. (Geiogamah, 2011, p. 8)

A similar viewpoint is shared by scholar Janet Snyder Neil (1986), who also includes ceremonies and performances events in the domain of Native American theater after establishing the importance of masks and headgear of the Northwest Coast Indians as elements of performance.

Although these ambivalent responses seem to reflect the much-discussed debate about the origins of theater in general, it is clear that most Native playwrights and authors agree that contemporary American Indian theater owes more to traditional storytelling than to rituals or ceremonies. This theory seems to be the most appropriate because although Native Americans performed different religious ritual dramas, they did not evolve into theater, as they never developed into secular art forms. On the contrary, it is through storytelling that the origins of contemporary Native American theater could be more clearly perceived for several reasons (López Pérez, 2011): first, there exists a narrator or storyteller; second, there is a story or plot which is told, acted out and developed; and third, there is a conclusion or moral that preserves the tribal cohesion and Native American cultural traditions. While these elements can certainly be found in contemporary American Indian theater, the situation is quite different as far as rituals are concerned. Even though it is possible to find a conclusion or moral in ritual practices, there is no storyteller or narrator, but a sort of facilitator of the 


\section{1-23 December, 2018 in Berlin - Germany}

magic that links together the physical and spiritual world which has always been inherent to American Indian cultures. There is no plot, either, since it would be subordinated to the purposes of a magic and religious act, whose end would not be known or certain. Therefore, it seems reasonable to establish a link between storytelling and performance through Native oral traditions that could possibly lead us to the origins of contemporary American Indian theater.

\section{The different perspectives regarding the emergence of Native American theater as a genre}

Contemporary Native American theater developed within the frame of the so-called Native American Renaissance, a term originally coined by Lincoln (1983) that refers to the period of greatest splendor for American Indian literature that followed the publication of $\mathrm{N}$. Scott Momaday's Pulitzer Prize House Made of Dawn in 1968. Influenced by the cultural revival of the late 1960s and early 1970s and marked by the civil rights movement, this new literary genre presented itself as a cultural, artistic and literary vehicle that gave American Indians the chance to present their own stories on stage and in writing from a realistic and authentic approach. However, there are still some discrepancies regarding the date of its emergence as a genre, as different dates continue to be provided by Native and non-Native authors and scholars alike. (López Pérez, 2011)

Wilmeth (2000) suggests that contemporary Native American theater could have emerged through the works published by the Cherokee dramatist Rollie Lynn Riggs ${ }^{4}$ in the 1930s, as he considers that "Riggs's emergence as a minor American playwright marked the beginning of a school of Native American playwrights" (p. 146). Yet, he makes clear that several American Indian dramatists coming after Riggs gained some recognition, and that Hanay Geiogamah stands out as the only Native playwright to have received national and critical attention through his collection of theater plays in 1980. A similar viewpoint is shared by Däwes (personal communication, November 25, 2007), who also talks about the relevance of Lynn Riggs in contemporary Native drama as one of the first events contributing to the beginnings of Native American theater. However, according to Huntsman (2000), the beginnings of contemporary Native American drama date back to the 1950s, the period in which the first efforts to form American Indian companies to perform and produce "both traditional dramas and works by new Indian playwrights" (p. 95), were carried out by Arthur Junaluska in New York. In addition, Geiogamah (2006) indicates that "the history of the contemporary, new Indian theater really begins in the 1960s" (p. 1), although he clearly explains how political, social and economic advances from the late 1940s until the early 1960 s gave a major push to the creation of this new literary genre.

Other critics such as Ann Haugo and Christy Stanlake trace the beginnings of contemporary Native American theater back to the early 1970s. Whereas Stanlake (2009) places its starting point in the transition from the late 1960s into the early 1970s-considering the founding of

\footnotetext{
${ }^{4}$ Riggs's most popular plays include Green Grow the Lilacs (1930), which became one of the world's greatest musicals, Oklahoma!, and The Cherokee Night (1936), a significant play that depicts the life of Native Americans in Oklahoma during the 1920s and 1930s.
} 


\section{1-23 December, 2018 in Berlin - Germany}

the Institute of American Indian Arts (IAIA) and the NATE as "the events most credited for stimulating contemporary Native American theater" (p. 8)-Haugo (2013) talks about the beginning of the "Native Theatre Movement" in the early 1970s by the Kiowa playwright Hanay Geiogamah and the formation of the NATE (p. 49). However, the Cherokee dramatist Diane Glancy does not provide any dates and continues to place the beginnings of contemporary Native American drama in the oral tradition: "Indians don't do well with specific dates. Maybe theatre began in pictographs, old cave drawings that seemed to move in the firelight" (personal communication, September 20, 2007, p. 2-3).

Despite the different dates and perspectives provided by critics and authors on the beginnings of contemporary Native American theater, it seems to be clear that there are several events that contributed to the emergence of this literary genre during the second half of the twentieth century. Although it is true that Lynn Riggs was the first Native playwright to publish some theater plays during the 1930s, he often neglected to point out his American Indian heritage and "the public of his time (the 1930s and 40s) did not perceive him as Native" (Däwes, personal communication, November 25, 2007, p. 2). As a result, "Lynn Riggs did not achieve the literary impact that would later lead to the emergence of contemporary Native American theater" (López Pérez \& Benali Taouis, 2016, p. 99), but he certainly contributed to paving the way for the development of a contemporary Native theater movement during the 1950s. Thus, the beginnings of contemporary indigenous drama can be said to be marked by the creation of the American Indian Drama Company-the first Native theater company founded in New York in 1956-the foundation of the IAIA with its theater program in the 1960s, the emergence of the Native American Renaissance in 1968, the production of Geiogamah's Body Indian by the NATE in 1972, and the first collection of Native American theater plays published by Hanay Geiogamah in 1980.

\section{The controversy about the geographical, political and cultural boundaries of contemporary Native American theater}

Although contemporary Native American theater refers to the large number of plays produced by American Indian dramatists in the United States, there are still some discrepancies about its geographical, political and cultural boundaries. Whereas some anthologies on Native American theater include only plays by American Indian dramatists, others contain some theater plays by First Nations playwrights. Examples include publications such as Stories of Our Way: An Anthology of American Indian Plays (1999), which only contains Native American theater plays; Seventh Generation: An Anthology of Native American Plays (1999), which includes six plays by Native American authors and one play by a First Nation dramatist; Keepers of the Morning Star: An Anthology of Native Women's Theater (2003), which contains eight Native American plays and one theatrical piece by a Native Canadian playwright; and finally, Footpaths and Bridges: Voices from the Native American Women Playwrights Archive (2008) and Performing Worlds into Being: Native American Women's Theater (2009), which combine both Native American and First Nations theater plays.

Regarding scholarship, it is also frequent to find essays on First Nations drama in critical works dealing with Native American theater or performance. Geiogamah and Darby's edited volumes American Indian Theater in Performance: A Reader (2000) and American Indian 


\section{1-23 December, 2018 in Berlin - Germany}

Performing Arts: Critical Directions (2010) serve as excellent examples, since both books incorporate some essays, analyses or discussions on Native Canadian theater. The same happens with Wilmer's edition of Native American Performance and Representation (2009), a book that includes an analysis of Monique Mojica's play Princess Pocahontas and the Blue Spots and a reference and analysis of the Kwakiutl peoples from British Columbia in an essay about the Pacific Northwest Performance.

The presence of First Nations drama in several publications about Native American theater and performance seems to indicate that "there are no cultural boundaries between the United States and Canada when dealing with indigenous experiences through Native theater" (López Pérez \& Benali Taouis, 2016, p. 104). As Däwes (2007) points out, in both countries indigenous peoples seem to be "united by a shared experience of colonization, as the practices of genocide, removal, educational restrictions, and cultural oppression have lastingly influenced the contemporary living conditions on both sides of the 49th parallel" (p. 21).

However, although there may be no substantive reasons to differentiate between the development of Native American and First Nations theater from a cultural perspective, there is a geographical and political boundary that should be respected, especially if one takes into consideration that the United States and Canada are two different countries with distinct legislation. Apart from this, these two nations have a different terminology for indigenous peoples, which could also be applied to theater itself: Native American/American Indian for the United States and First Nations/Native Canadian for Canada. In addition, from a political, demographic and literary point of view, there are several reasons that usually account for the distinction between Native American and Native Canadian theater. The Ojibway playwright Drew Hayden Taylor talks about the stronger political representation and public presence of indigenous peoples in Canada, better funding conditions and more facilities for Native Canadian theater and the inclusion of First Nations drama in the Canadian literary canon (personal communication, August 8,2007 ) as frequently cited reasons for making clear that First Nations theater differs from and is at a clear advantage regarding its Native American counterpart.

Another aspect that continues to be under debate regarding the mapping of contemporary Native American theater is the inclusion of Hawaii. The discussion arises from the fact that Hawaii is believed to have been originally inhabited by Polynesian voyagers in the Marquesas Islands, thus being historically and culturally more tied to the islands in the southern Pacific than to Native American cultures. It is not surprising, then, that few anthologies include theater plays by Native Hawaiian dramatists. Only Seventh Generation (1999) and Footpaths and Bridges (2008) contain two Native Hawaiian plays. On the contrary, Stories of our Way (1999) does not include any theater play by Native Hawaiian playwrights, and Keepers of the Morning Star (2003) excludes Native plays from Hawaii, but includes some First Nations theatrical pieces.

This controversial situation clearly indicates that the mapping of contemporary Native theater's boundaries should be revised and refined, "since whether to include Native drama from Canada and to exclude indigenous theater from the $50^{\text {th }}$ state of the union continues to be debatable" (López Pérez \& Benali Taouis, 2016, p. 104). At the same time, there are similarities in the histories of both Native Americans and Native Hawaiians (Benham \& Heck, 1998) that should also be taken into consideration. As Iyall Smith (2006) points out, they 


\section{1-23 December, 2018 in Berlin - Germany}

"experience a similar social, economic and political status within the United States and in the various localities" (p. 7). In addition, some critics have offered arguments in favor of a preEuropean contact between Polynesians and some Native Americans from southern California and have also provided details about historical interactions between Native Hawaiians and Native Americans during the nineteenth and twentieth century, especially since World War II (Drechsel, 2008). According to these interactions, American Indians and Native Hawaiians "have shared much in common because of similar experiences in their colonial and recent history, whence they have understood more of each other's concerns than divide-andconquer-minded colonists and their descendants have realized or liked to admit" (Drechsel, 2008, p. 75).

Finally, these similar experiences are frequently found and shared through indigenous theater, as there are Native plays from Hawaii that deal with indigenous concerns that are very much common in theater plays by Native dramatists in the continental United States. A clear example is the collection of plays Hawai'i Nei: Island Plays (2002) by the Native HawaiianSamoan playwright Victoria Nalani Kneubuhl, who offers three different theatrical pieces dealing with the lives of indigenous peoples after Western contact, oppression, assimilation and the struggle to maintain their Native cultural heritage. There are thus good grounds for considering the inclusion of Native theater from Hawaii into the realm of Native American theater.

\section{The Native theater scene today: obstacles and initiatives}

Although only a handful of plays were available when contemporary Native American theater emerged around the 1950s, today hundreds of Native American plays exist. As Däwes (2013) confirms, "there are currently over 250 published and far over 600 unpublished plays by some 250 Native American and First Nations playwrights and theatre groups on the North American market" (p. 13). This abundance of primary sources is available through the numerous collections published by individual playwrights since the 1980s and the various anthologies appearing since $1999^{5}$. In addition, Native American theater plays are also accessible through Alexander Street Press's North American Indian Drama, an online collection of more than 250 theater plays by both Native American and First Nations playwrights, and the Native American Women's Playwrights Archive at Miami University of Ohio's King Library, which collects both published and unpublished plays by Native women playwrights of America.

Despite this abundance of material, scholarship in the genre has just begun to gain momentum. Although the first collection of critical essays on American Indian drama was published in 2000, it was not until the later part of the first decade of the twenty-first century that several publications in the field started to appear more frequently and prominently until the present day. However, even though these different scholarly works have covered multiple issues and perspectives on Native theater, which account for the interest generated by the field and demonstrate "how American Indian drama has moved from specific and cultural

\footnotetext{
${ }^{5}$ Most of these collections and anthologies were compiled by Haugo (2000b) and Däwes (2007). More recently, these works have been reviewed by Haugo (2013) and by López Pérez \& Benali Taouis (2016).
} 


\section{1-23 December, 2018 in Berlin - Germany}

communities into larger and more generalized audiences" (López Pérez \& Benali Taouis, 2016, p. 107), many more voices and angles are needed. This does not, of course, mean that the Native theater scene remains without problems because there are several factors that are clearly contributing to slowing down the progressive and consolidated development of the genre. According to Geiogamah (2013), the main problem lies in the insufficient funding from foundations, state, federal and local governments and tribes, which is obviously translating into few productions, small audiences and "sustainability challenges among the few existing companies and groups" (p. 330). At the same time, American Indian theater also faces some difficulties in reaching tribal audiences, as urban productions do not always get to rural areas or reservations. In addition, there is theatrical work that usually passes unnoticed at the national level and is generally lost in terms of critical and professional visibility. Such is the case of the community-based theater developed by those "Native artists traveling to Native communities, urban or reservation, working from the community's stories, and developing work that might only be staged once or twice" (Haugo, 2013, p. 71).

In spite of this situation, some initiatives are slowly taking place in order to reinforce the visibility of the genre and to promote the work of Native playwrights. One of the most outstanding approaches comes from Project HOOP (Honoring Our Origins and People), a national, multidisciplinary initiative to promote the development of Native American theater and performing arts, which was co-founded and co-directed by Hanay Geiogamah and Jaye T. Darby in 1996. During the past years, Project HOOP has worked in collaboration with the American Indian Studies Center at UCLA, sponsoring different conferences on Native American theater and releasing various publications on the genre through the Native American Performance and Critical Studies Series. In addition, Project HOOP has also sponsored some videoconferences so as to gather different Native theater artists in the country in order to carry out live performances and read excerpts of new plays (Geiogamah, 2013). Since these teleconferences have been successful and they have helped reduce funding costs, Geiogamah (2013) asserts that "more online American Indian theater courses and performance events will appear in the very near future, and this development will give Indian theater a nice shot of twenty-first century techno adrenaline" (p. 334). Equally important to note is the significant effort made by different established institutions, such as the Haskell Indian Nations University (HINU), whose Art and Theater Programs contribute to the development of Native theater and provide "a forum for the production of Native playwrights" (HINU, 2018, Art and Theatre Programs, para. 2); the Yale Indigenous Performing Arts Program (YIPAP), which continues to produce and host staged readings and performances of Native American plays; the New Native Theatre in the Twin Cities, which has also been hosting and producing different Native theater plays since its debut in 2009 under the artistic direction of the Navajo playwright Rhiana Yazzied; La MaMa Theater Experimental Club in New York City, whose Indigenous Initiative Program has included various Native theatrical productions; Arena Stage in Washington D.C., which has also produced some Native American plays under its Women's Voices Power Play Cycle; and finally, Native Voices at the Autry, which is the United States' only Equity theater company devoted completely to producing new works by Native American and First Nation playwrights. The company presented its $24^{\text {th }}$ Festival of New Plays last June and is currently presenting the $8^{\text {th }}$ Annual Short Play Festival. 


\section{1-23 December, 2018 in Berlin - Germany}

All these initiatives, together with the great diversity of Native American plays and a significant amount of scholarship, advocate a good visibility for Native American theater. However, much more needs to be done-both from a theoretical and practical approach-in order to develop a self-sustaining Native theater. As Geiogamah (2017) puts it, "we have a long way to go to fully develop a confident, mature and productive American Indian theater and also an American Indian cinema. What we have now is actually a respectable beginning" (p. 182). In this respect and from a practical perspective, the Kiowa/Delaware playwright suggests that Native theater artists continue to experiment with the benefits of technology by gathering via teleconference to perform different Native theater plays, read excerpts of new plays and productions, offer online American Indian theater courses and adapt Native stage works for YouTube runs. At the same time, Geiogamah (2017) also encourages the collaboration with theaters of color, with Native American studies departments and programs, and also with TV and film studios in Hollywood. From a more theoretical point of view, many more voices, angles and perspectives are needed by both Native and non-Native scholars and critics around the globe. Scholarship in the field should continue to expand in order to deeply explore and analyze different aspects in Native American theater plays. Examples include questions of gender and gender relations (Däwes, 2013), themes of acculturation, survival, oppression, poverty, violence, generational relationships, confrontation between Native traditional values and white American values, customs and beliefs, the contrast between contemporary American Indian life on the reservations and in the cities, and a long etcetera. At the same time, more attention should be paid to the differences between urban and reservation theater groups, the relationship between theatrical communities and their audiences (Däwes, 2013), similarities and differences of American Indian theater with respect to Western theater and other ethnic literatures, and the great work and effort of theater companies and institutions to produce and host Native plays. As Geiogamah (2013) puts it, "We have only scratched the surface, and the larger possibilities are visible and real" (p. 346).

\section{Conclusions}

Although contemporary Native American theater emerged in the second half of the $20^{\text {th }}$ century and currently has a great amount of theater plays, an impressive history of theater companies and a significant body of scholarship, criticism and analysis, the genre still does not enjoy a consolidated development. To start with, American Indian drama has a long history of silencing, displacement, controversy and difficult recognition that has been certainly harmful for its development as a genre. In addition, even though Native theater draws from an extensive oral tradition, which usually included storytelling, ceremonies and rituals with certain theatrical elements, whether or not these traditions can be seen as early forms of theater or a simple devaluation of sacred rituals still remains debatable. At the same time, there is a significant controversy regarding the geographical, political and cultural boundaries of contemporary Native American theater that clearly indicates that the mapping of the genre needs to be revised and refined. Apart from this, although hundreds of Native theater plays exist nowadays and the growth in the field has led to an impressive amount of Native theater artists and actors, the lack of funding from foundations, arts organizations and tribal communities obviously results in few productions and a clear lack of visibility and critical 


\section{1-23 December, 2018 in Berlin - Germany}

recognition for contemporary Native American theater. In spite of this situation, some initiatives are slowly taking place in order to promote the visibility of the genre and to keep the Native theater movement alive. Similarly, the works by both Native and non-Native authors and scholars are certainly helping explore indigenous theater from different perspectives, angles and voices. However, more work is needed to fully develop a confident and stable literary genre. Native American theater needs more interest and support as well as a stronger collaboration with tribal communities, theater companies, arts organizations, institutions, museums and universities. In addition, scholarship in the field should also continue to expand in order to explore and analyze new characteristics, aspects, themes and topics regarding the genre. In other words, the surface of Native American theater has certainly been scratched, but obviously more efforts are needed in order to unleash the full potential of this vibrant literary genre.

\section{References}

Alexander, H. B. (1926). "For an American Indian theater". Theater Arts Monthly, vol. 10, no. 3, pp. 191-202.

Armstrong, A. E., Johnson, K. L., and Wortman, W. A. (Eds.). (2009). Performing Worlds into Being: Native American Women's Theater. Oxford, Ohio: Miami UP.

Benham, M.K.P., and Heck, R. H., (1998). Culture and Educational Policy in Hawai'i: The Silencing of Native Voices. New York and London: Routledge.

Cayuga, C. (1991, December 9). Meeting at the crossroads: What direction for the 1990s? Lecture given at New World Theater Tenth Anniversary Play Festival and Conference.

D'Aponte, M. G. (Ed.). (1999). Seventh Generation: An Anthology of Native American Plays. New York: Theatre Communications Group.

Darby, J. T., and Fitzgerald, S. J. (Eds.). (2003). Keepers of the Morning Star: An Anthology of Native Women's Theater. Los Angeles: UCLA American Indian Studies Center.

Däwes, B. (Ed.). (2007). Native North American Theater in a Global Age: Sites of Identity Construction and Transdifference. Heidelberg: Winter.

Däwes, B. (2013). "Performing memory, transforming time: History and indigenous North American drama". In Birgit D. (Ed.), Indigenous North American Drama: A Multivocal History (pp. 12-26). Albany: State University of New York.

Däwes, B., and Maufort, M. (Eds.). (2014). Enacting Nature: Ecocritical Perspectives on Indigenous Performance. Brussels: Peter Lang.

Drechsel, E. J. (2008). "Contact between Native Americans and Native Hawaiians since World War II". Pacific Studies, 31(2), pp. 53-85.

Geiogamah, H. (1980). New Native American Drama: Three Plays. Norman: University of Oklahoma Press.

Geiogamah, H. (2006). "Project HOOP: Advancing critical conversation and scholarship in Native Theater and Performing Arts". Unpublished manuscript. Microsoft Word file.

Geiogamah, H. (2011). Ceremony, Spirituality and Ritual in Native American Performance: A Creative Notebook. Los Angeles: UCLA American Indian Studies Center.

Geiogamah, H. (2013). "American Indian theater 2013: Not running on empty yet". In Robert W. (Ed.), The World of Indigenous North America (pp. 330-346). New York: Routledge. 


\section{1-23 December, 2018 in Berlin - Germany}

Geiogamah, H. (2017). “A future for American Indian theater?". In Chinua T. (Ed.), Theater and Cultural Politics for a New World (pp. 173-182). New York: Routledge, Taylor \& Francis Group.

Geiogamah, H., and Darby, J. T. (Eds.). (1999). Stories of Our Way: An Anthology of American Indian Plays. Los Angeles: UCLA American Indian Studies Center.

Geiogamah, H., and Darby, J. T. (Eds.). (2000). American Indian Theater in Performance: A Reader. Los Angeles: UCLA American Indian Studies Center.

Geiogamah, H., and Darby, J. T. (Eds.). (2010). American Indian Performing Arts: Critical Directions. Los Angeles: UCLA American Indian Studies Center.

Haskell Indian Nations University. (2018). Art and Theatre Programs. Retrieved from https://www.haskell.edu/academics/art-theatre/about-art-theatre/

Haugo, A. (2000a). " 'Circles upon circles upon circles': Native women in theater and performance". In Hanay G., and Jaye T. D., (Eds.), American Indian Theater in Performance: A Reader (pp. 228-255). Los Angeles: UCLA American Indian Studies Center.

Haugo, A. (2000b). "Contemporary Native American theater: Bibliography and resource materials". In Hanay G., and Jaye T. D., (Eds.), American Indian Theater in Performance: A Reader (pp. 367-390). Los Angeles: UCLA American Indian Studies Center.

Haugo, A. (2005). "American Indian theatre". In Joy P. and Kenneth M. R., The Cambridge Companion to Native American Literature (pp. 189-204). Cambridge: Cambridge University Press.

Haugo, A. (2013). "Native American drama: A historical survey". In Birgit D. (Ed.), Indigenous North American Drama: A Multivocal History (pp. 49-72). Albany: State University of New York.

Heath, S. A. (1995). The development of Native American theater companies in the Continental United States (Unpublished doctoral dissertation). University of Colorado-Boulder.

Huntsman, J. F. (2000). "Native American theatre". In Hanay G., and Jaye T. D., (Eds.), American Indian Theater in Performance: A Reader (pp.81-103). Los Angeles: UCLA American Indian Studies Center.

Huston-Findley, S., and Howard R. (Eds.). (2008). Footpaths and Bridges: Voices from the Native American Women Playwrights Archive. Ann Arbor: University of Michigan Press.

Iyall Smith, K. E. (2006). The State and Indigenous Movements. New York and London: Routledge.

Jenkins, L. W. (1975). The performances of the Native Americans as American theater: Reconnaissance and recommendations (Unpublished doctoral dissertation). University of Minnesota.

King, B. (2000). "Emergence and discovery: Native American theater comes of age". In Hanay G., and Jaye T. D. (Eds.), American Indian Theater in Performance: A Reader (pp.165168). Los Angeles: UCLA American Indian Studies Center.

Kneubuhl, V. N. (2002). Hawai'i Nei: Island Plays. Honolulu: University of Hawai'i Press.

Krupat, A. (1989). The Voice in the Margin: Native American Literature and the Canon. Berkeley: University of California Press.

Lincoln, K. (1983). Native American Renaissance. Berkeley: University of California Press. 


\section{International Conference on}

\section{SOCIAL SCIENCE, HUMANITIES \& EDUCATION}

\section{1-23 December, 2018 in Berlin - Germany}

López Pérez, S. (2011). El teatro nativo-americano contemporáneo: evolución hacia una identidad de síntesis (Unpublished doctoral dissertation). Universidad Complutense de Madrid.

López Pérez, S., and Benali Taouis, H. (2016). "Native American theater: A concise history". Miscelánea: A Journal of English and American Studies, vol. 54, pp. 93-111.

Neil, J. S. (1986). "Masks and headgear of Native American ritual/theatre on the Northwest Coast". Theatre Journal, vol. 38, no. 4, pp. 453-462.

Schäfer, H. (2013). "A short history of Native Canadian theatre". In Birgit D. (Ed.), Indigenous North American Drama: A Multivocal History (pp. 29-47). Albany: State University of New York.

Stanlake, C. (2009). Native American Drama: A Critical Perspective. Cambridge: Cambridge University Press.

Wilmer, S.E. (Ed.). (2009). Native American Performance and Representation. Tucson: The University of Arizona Press.

Wilmeth, D. B. (2000). "The American Indian on stage and in drama". In Hanay G., and Jaye T. D. (Eds.), American Indian Theater in Performance: A Reader (pp. 127-156). Los Angeles: UCLA American Indian Studies Center.

Wilmeth, D. B., and Miller T. L. (Eds.). (1996). The Cambridge Guide to American Theatre. Cambridge: Cambridge University Press. 